Northern Review

yukoncollege.yk.ca/review

\title{
"Steering Our Own Ship?" An Assessment of Self-Determination and Self-Governance for Community Development in Nunavut
}

\author{
Roger Ritsema, Jackie Dawson, Miriam Jorgensen, \\ and Brenda Macdougall
}

\begin{abstract}
Climate change, the global demand for energy, and the depletion of easily accessible natural resources has led to an increase in mining activities in the Arctic, including in Nunavut, a region rich in resources but remote in comparison to the rest of Canada. Nunavut is a predominantly Inuit socio-political region created in 1999 via the Nunavut Act and the Nunavut Land Claims Agreement (NLCA) (1993). The NLCA also enshrined the Inuit right to manage the region's minerals and other natural resources. Yet, despite this power to "steer their own ship," Inuit communities struggle to maximize the benefits from resource development. Pond Inlet is a coastal hamlet on Baffin Island close to the newly operational Mary River iron ore mine, an open-pit mine with the potential to bring significant economic opportunities to the region. Using a framework developed by the Harvard Project on American Indian Economic Development, a case study of Pond Inlet highlights factors that contribute to and hinder Arctic Aboriginal communities' successful local development. A total of 47 semi-structured interviews were conducted with key informants in Pond Inlet and in the territory's capital, Iqaluit. Findings underscore the importance of Indigenous community self-determination, effective and culturally relevant governing institutions, and clear visioning for the future. In Pond Inlet, key barriers to maximizing local benefits relate to institutional and governance challenges. Evidence from this study suggests that Pond Inlet will better succeed with local community development by strengthening its governance mechanisms to support the goals of self-determination.
\end{abstract}




\subsection{Introduction}

In the Canadian Arctic, environmental changes such as reduced sea ice and melting permafrost (ACIA, 2004; IPCC, 2014) are increasing access to remote Arctic areas rich in oil, gas, and minerals (Lemmen, Warren, Lacroix, \& Bush, 2008; Gauthier et al., 2009; Prowse et al., 2009). This new access, coupled with the continual global demand for energy resources, has the potential to usher in an era of highly active resource extraction across the Canadian North (Prowse et al., 2009; RESDA, 2012, 2013; Rhéaume \& Caron-Vuotari, 2013). The federal Government of Canada, the territorial Government of Nunavut, and Nunavut Tunngavik Incorporated (NTI), an Inuit corporation created as a result of the Nunavut Land Claims Agreement (NLCA), all agree that mining is an important driver of economic growth in the region-although their specific priorities and goals differ. For example, as it has throughout its history and in alignment with current political preferences, Canada views Arctic resource development as a means to support the national economy. By contrast, both NTI and the Government of Nunavut regard mining and other forms of economic development as a way to ensure that Inuit communities are not only economically sustainable but able to socially and culturally thrive.

The national-scale benefits of mining in the North are clear, as are the financial benefits for private sector companies backing extraction efforts. What is not clear is the extent to which small Inuit communities in Nunavut will positively benefit from resource development within their homeland over the longer term. Considering the boom-bust dynamics of resource dependent regions, it is also unclear how communities can best leverage regional mining activities to create self-sustaining and culturally relevant economies.

Related questions have been the focus of nearly three decades of research by the Harvard Project on American Indian Economic Development (identified hereafter as the Harvard Project) and 15 years of work by its sister organization, the Native Nations Institute at the University of Arizona (NNI) (see HPAIED, 2015; and NNI, 2015). Harvard Project studies show that selfdetermination, especially when backed by effective, Indigenous institutions of government, is the fundamental factor in Indigenous nations' successful economic and community development. Given that the settled NLCA recognizes Inuit authority to develop their homeland and provides for the creation of Inuit legal and political institutions, one might assume that Inuit communities in Nunavut are in an excellent position to exercise selfdetermination on behalf of economic development. So why do communities across the region continue to struggle? 
The research presented here attempts to understand why Nunavut communities are struggling despite their ostensible "self-determination." We use as a case study the community of Pond Inlet, Nunavut and a framework developed by the Harvard Project and NNI in order to identify existing characteristics of community governance that may-or may not-support successful local development. This article proceeds as follows: Section 2.0 presents data about the case study community and describes the research findings and resultant analytical framework of the Harvard Project, Section 3.0 describes the methodology used for this case study, Section 4.0 presents and discusses findings, and Section 5.0 provides a conclusion.

\subsection{Case Study and Conceptual Approach}

\subsection{The Community of Pond Inlet}

Pond Inlet $\left(72.7^{\circ} \mathrm{N}, 77.9^{\circ} \mathrm{W}\right)$ is a coastal community of just over 1,500 people (90\% Inuit) located on northern Baffin Island in the Qikiqtaaluk/Baffin region of the Nunavut territory, the largest and most northern territory of Canada (Statistics Canada, 2013). Nunavut's population is overwhelmingly young, with a median age of 22 as compared to 39 years for the national population (Statistics Canada, 2012), and a population growth rate nearly double the Canadian average (Statistics Canada, 2011). As one of the larger communities in Nunavut, Pond Inlet's population likely reflects these territory-wide averages.

Politically, Pond Inlet is classified as an incorporated hamlet, which is equivalent to town status but without taxation powers. The community began running its own affairs on 1 April 1975, and is gaining additional responsibilities as devolution of governance continues in the North, from national to territorial to local levels. Devolution is part of the 1993 settling of the Nunavut Land Claim Area, which recognizes that Nunavummiut (collectively the Inuit living in Nunavut) have an inherent right to Inuitowned lands (and its resources) as affirmed in Canadian law. As a result, Nunavummiut have gained a measure of self-determination over their political and economic affairs within their homeland (see NTI, 2015b).

Pond Inlet's formal economy is service-based with public administration, retail trade, educational services, construction, health care, and social services sectors dominating labour force participation (Statistics Canada, 2013). Although more difficult to quantify, informal activities such as subsistence hunting, fishing, and gathering, as well as the practice of cultural arts, are also important parts of the overall Nunavut economy (NEF, 2013) and cultural heritage and identity of the people of the region. Unfortunately, 
like many other Inuit communities in Nunavut, Pond Inlet struggles with social and economic issues such as low educational attainment, high unemployment, and elevated rates of poverty and poor health (Coates \& Powell, 1989; SEDSG, 2003; Angell \& Parkins, 2010; NSCG, 2009; Parlee \& Furgal, 2012; Peterson, 2012; NEF, 2013; CPC, 2014).

More recently, Pond Inlet has become known for its close proximity to one of the largest iron ore deposits that climate change has helped make accessible for development (Government of Canada, 2009; AANDC, 2012; BIMC, 2012). The Mary River open-pit iron ore mine has an estimated operational life of at least twenty years, and is expected to generate thousands of jobs while in operation, triple the growth rate of the territory's annual gross domestic product, and provide nearly $\$ 5$ billion in tax revenue and royalties (Waldie, 2011; BIMC, 2012). Employment at the mine is expected to peak at 2,700 workers during the construction phase and employ 950 people during the operation phase (BIMC, 2012). If mine development meets expectations for economic growth and opportunity as reflected in the NLCA and the Mary River Inuit Impact Benefit Agreement (MRIIBA), the Inuit of Pond Inlet (sometimes referred to as Mittimatalikmiut) could benefit from increased employment opportunities, improved local infrastructure, greater potential for entrepreneurial ventures, and new local services. In turn, these changes could decrease local poverty rates and improve health and wellbeing indicators (NTI, 1997; SEDSG, 2003; Government of Nunavut, 2007; Government of Canada, 2009; BIMC, 2012). The experiences of some other northern communities underscore the possibilities (NEF, 2013).

However, prior studies also show that northern development can cause a range of negative impacts for local Aboriginal communities when their rights and needs are not held paramount. These include boom and bust economies; increased drug and alcohol use caused by the influx of money and people into previously isolated areas; increased rates of crime, violence, and suicide as a result of social disturbance; disruption of traditional land-based economies and the subsequent loss of cultural traditions; and environmental degradation as a consequence of unchecked resource extraction (Duhaime et al., 2003; Buell, 2006; Angell \& Parkins, 2010; Peterson, 2012).

\subsection{A Summary of Harvard Project Research Findings and Model}

Since 1987, the Harvard Project-and since 2001, the Native Nations Institute-has worked with American Indian nations in the United States to better understand the determinants of sustained social and economic development (HPAIED, 2015; NNI, 2015). They have asked, "[W] hat accounts for some American Indian nations' community development success while 
other nations continue to struggle?" Research findings point to several key factors: self-determined decision making (the exercise of "de facto sovereignty"); effective and culturally legitimate institutions of government; strategic vision and strategic thinking; and public-spirited, nation-building leadership (Figure 1) (Cornell \& Kalt, 1992, 1998, 2007).

\begin{tabular}{|c|}
\hline COMMUNITY DEVELOPMENT SUCCESS \\
\hline $\begin{array}{c}\text { Nation-building, public-spirited leadership } \\
\text { Formal and informal leaders establish foundations for sustained community development }\end{array}$ \\
$\begin{array}{c}\text { Strategic Vision \& Strategic Thinking } \\
\text { Community sets long-term priorities and links its decisions to them }\end{array}$ \\
\hline $\begin{array}{c}\text { Effective Institutions } \\
\text { Stable, effective, and fair }\end{array}$ \\
\hline \\
Practical decision-making power in the hands of the community; \\
this is a political matter, not simply an organizational issue
\end{tabular}

Figure 1. The Harvard Project framework (adapted from Cornell \& Kalt, 2007).

Self-determination matters. Harvard Project research found that selfdetermination matters because it removes the objectives of colonial governments from decision making and replaces them with Indigenous objectives. It provides Native nations with greater control over financial, natural, and programmatic resources. It leads Native community members to require more accountability from their public servants, and as a result, performance incentives are stronger: public servants answerable to local Indigenous communities consistently out-perform external decision makers on matters as diverse as law enforcement, natural resource management, economic development, health care, and social service provision (Krepps \& Caves, 1994; Dixon, Shelton, Roubideaux, Mather, \& Mala Smith, 1998; Wakeling, Jorgensen, Michaelson, \& Begay, 2001; Berry, 2009; Goldberg \& Champagne, 2012; Cornell, Jorgensen, Rainie, \& Starks, 2013).

Institutions matter because they are key tools that an Indigenous community can use to implement its self-determined choices. On the one hand, a Native nation's governing institutions must be capable and effective. For instance, evidence suggests that governance capability is reflected in efficient administrative procedures, fair and independent mechanisms for dispute resolution, and systems that separate politics from day-to-day business and program management (Cornell \& Kalt, 1998; Jorgensen \& Taylor, 2000; Jorgensen, 2004; Trosper, Nelson, Hoberg, Smith, \& Nikolakis, 2008). 
Culture matters. On the other hand, a Native nation's governing mechanisms, laws, policies, and procedures must be its own. A fit with the community's contemporary political culture-a "cultural match"-helps ensure that citizens respect their government and use it to achieve community goals (Trosper, 1995; Jorgensen, 2000; Cornell \& Kalt, 1993, 1995, 1997, 2000). In other words, culture matters.

Strategic thinking matters because it helps Native nation leaders and citizens shift their focus from the short term to the long term, and in so doing, shift from responding to crises, pursuing only what can be funded, and concentrating on isolated problems to implementing the nation's vision. A strategic orientation puts them on track toward the future they desire (Cornell \& Kalt, 2007; Zaferatos, 2015).

Leadership matters because when Indigenous leaders, whether elected, appointed, hereditary, grassroots, or spiritual, abide by the rules and policies of their nation's self-determined governing system and enliven those institutions by their example, they increase the chances that Indigenous selfdetermination and self-governance will endure. And when Native nation leaders introduce new knowledge, challenge assumptions, convince people that things can be different, propose change, and mobilize the community to take action, they make socio-economic change imaginable (Begay, Cornell, Jorgensen, \& Pryor, 2007; Cornell, Jorgensen, Kalt, \& Spilde Contreras, 2007; Cornell \& Kalt, 2007).

These are significant insights into how American Indian nations have created successful development for themselves. They also provide a framework for understanding whether Native nations have the capacity for realizing their goals, which is the approach of this research.

In applying the "nation-building model" (as the Harvard Project and Native Nations Institute research findings often are termed) to Pond Inlet, two caveats are in order. First, the different nation-state context may not give rise to the same keys to success. In fact, some researchers have argued that the approach does not apply to the Canadian setting at all (e.g., Simeone, 2007). This research cannot answer that question comprehensively, but there are ways to test the accuracy of the observations it yields for the single case studied. The broader question of applicability to Canada, or even the Arctic, is left to future research.

Second, the Harvard Project research evaluated tribal success, not the success of individual communities within a Native nation or Indigenous group. Arguably, the Inuit people of Nunavut as a whole offers a more comparable political scale to the polities studied in previous Harvard 
Project research. Nevertheless, we apply the framework to the community/ hamlet level because the Inuit traditionally functioned both politically and economically in small, autonomous, mobile groups dependent on hunting, fishing, and gathering. As such, their traditional forms of governance were more localized to small groups. Even after the Canadian federal government, Christian missionaries, and the Royal Canadian Mounted Police began to insist in the 1960s that Inuit settle permanently, Inuit in Pond Inlet have continued to focus their social and political lives at the hamlet level.

\subsection{Research Methods}

Pond Inlet is the closest community $(160 \mathrm{~km})$ to Baffinland Iron Mines Corporation's (Baffinland) Mary River Project and is situated along the mine's proposed shipping route. These characteristics mean Pond Inlet has much to gain (or lose) as a consequence of resource development. The situation also makes it easier to evaluate whether the local Inuit community are appropriately equipped-according to the findings of Harvard Project research - to realize the promise of wealth from mining and move toward their community goal of alleviating the multi-generational impact of colonial policies.

To better understand the factors influencing successful local development, data were gathered through extensive review of relevant literature and via semi-structured interviews between August and September of 2013.

Using a purposive snowball sampling methodology (Patton, 2002), interviews first were conducted with residents in Pond Inlet and then with regional decision makers in Iqaluit. Preliminary contacts with residents of the hamlet provided effective entry points into relevant social and professional circles so that interviews with key community informants could be arranged (Secor, 2010). The overall response rate to requests for interviews was $84 \%$ : 56 requests were made, 47 were accepted, and 9 respondents declined. No pre-determined number of interviews was set, but using Krueger's (1988) guidance on saturation, interviews were capped at 47 . These included 31 one-hour, face-to-face interviews with community members in Pond Inlet and 16 interviews with regional decision-makers in Iqaluit. Interviews were conducted primarily in English, although two were conducted in Inuktitut using a local interpreter. All respondents and interpreters were offered "subject fees" for their time and were paid a conventional amount of $\$ 50$ per interview regardless of duration, as per conventions in the region (ITK and NRI, 2007). 
In Pond Inlet, 39\% of interviewees were female and $61 \%$ were male. The sample population included self-identified elders $(n=2)$, youth $(n=3)$, artists $(n=3)$, local and territorial government employees $(n=11)$, business managers/entrepreneurs/tourism industry professionals $(n=7)$, teachers $(n=2)$, and unemployed individuals $(n=3)$. In Iqaluit, $25 \%$ of the interviewees were female and $75 \%$ were male. This sample population consisted of regional decision makers affiliated with the federal government $(n=2)$, the territorial government $(n=9)$, local government $(n=1)$, Inuit organizations $(\mathrm{n}=2)$, economic development organizations $(\mathrm{n}=2)$, and a non-governmental organization $(\mathrm{n}=1)$.

Both sets of interviews were structured around questions related to Harvard Project findings. Interviews were recorded by hand using shorthand notation and transcribed directly after each interview for completeness and accuracy. Taking notes by hand made for a more relaxed interview setting, a stronger rapport with respondents, and more candid responses (Dooley, 1995; Dunn, 2010; Secor, 2010). Interview coding and data sorting were done manually. Data analysis was an iterative process guided by constant comparison methodology (see Glaser \& Strauss, 1967; Strauss \& Corbin, 1990). The transcription process facilitated constant comparisons because analysis began immediately after each interview and was ongoing. Emerging concepts were integrated into subsequent interviews and tested in ongoing analysis.

Prior to finalizing research results, the primary researcher shared study findings in person with the community for the purpose of validation and data extension. A community report of findings was made available in both English and Inuktitut and distributed to all participants. It was even more widely distributed throughout the community via the Pond Inlet Facebook group. The primary researcher also set up a weekend table at the community co-op to interact, explain, and discuss the findings (the table was advertised by poster and on local radio). The response from the community was generally positive and supportive, and no major changes to the observed findings were requested. Most residents felt that the findings would be useful to the community as it continues to grapple with the implications of the mine. (N.B., these engagements also allowed us to assess whether the Harvard Project framework was useful to this particular case.) 


\subsection{Results and Discussion}

The findings and results presented here are structured around four questions related to the Harvard Project framework: What is the status of self-determination in Pond Inlet? Do the Pond Inlet Inuit (Mitimatalkimiut) have effective institutions of self-government? Do Pond Inlet's decision making structures-and resultant decisions - reflect cultural match? And, does Pond Inlet have a strategic vision and the leadership to operationalize it?

\subsection{What is the Status of Self-Determination in Pond Inlet?}

The overwhelming majority of respondents felt that the Inuit of Pond Inlet lack self-determination. This is noteworthy because according to the terms of the NLCA, the government of Canada acknowledges the Nunavut Inuit's right to self-determination (NTI, 2015a). The NLCA also requires resource

companies to negotiate Inuit Impact Benefit Agreements (IIBAs) for all major projects, providing Inuit with the ability to influence development in their homeland. So why do the residents of Pond Inlet feel such a profound lack of control?

The reality is that the NLCA retains significant power for Canada, and does so in a variety of ways. First, Nunavut was created as a territory within the nation-state of Canada, not as an autonomous region. Second, the federal government holds decision-making power over non-renewable resource development on Crown lands (more specifically, on those lands not included in the NLCA) (White, 2009). Third, and importantly, after a proposed resource project on Inuit-owned lands has passed territorial regulatory reviews, the federal minister of Aboriginal Affairs and Northern Development Canada (AANDC) has final approval over the conditions that will allow the project to progress (NTI, 2004; also see CBC, 2015a). Thus, the federal government is in some cases the "go, no-go" decision maker through its role as the final project approver and, more subtly but also more powerfully, through its ability to invest in infrastructure, training, and other factors that can make a project appeal to the private sector and become a success for local communities.

One way that Canadian and Nunavut officials do support the principle of local input is through formal community meetings, as set out in consultation protocols within the NLCA (NTI2015a). The meetings are intended as a means for regulators, industry representatives, and community members to discuss development plans, economic initiatives, and opportunities for residents. In general, however, local residents do not regard these information sessions as the appropriate mechanism for asserting their rights in the development 
process. Thus, interviewees reported feeling that, as individuals, they had no real power to affect the course of the Mary River Project. Typical points made by residents were: "Individuals have no say in development" (NF4), and "It is unclear if the community has a voice or if decisions are made for them" (NF20).

Notably, Pond Inlet Inuit residents also felt that their "local government," the elected municipal body, was powerless to ensure that development took local needs and values into account. Reflecting on the hamlet's influence, one resident said, "Pond has no control over development, it is done by regulatory boards" (NF4). Another noted, "Pond [Inlet] is not autonomous in making [development] decisions because it must rely on federal and territorial [governments] for funding and other things" (NF2).

Ultimately, residents of Pond Inlet appear to have concluded that local needs and values are ignored by governments and agencies with more power than they have. This sense of powerlessness has, in turn, made the people of Pond Inlet apathetic about the consultative process at the local level ("only certain people seem to show up, the same eleven people" [NF20]). This further devalues the primary mechanism that regional, territorial, and Canadian government use to provide the local Inuit community with input into the development process. At the regional level, one decision maker explained this outcome, arguing that, "Inuit have been consulted to death" (NF31), which further suggests that consultation has become a one-way street: a lot of it occurs, but it is not the collaborative mechanism that it needs to be to generate even a measure of local control.

Harvard Project and NNI research points to the importance of "assertions" of sovereignty over decision making or "assertions" of selfdetermination. In Pond Inlet, it does not appear that such assertions of selfdetermination-community-level actions that might help them have more influence in decision making - have yet occurred. This is exacerbated by the fact that local residents lack a full understanding of their rights and powers. For example, a majority of key-informant respondents noted that there is a poor level of understanding among local residents about mining issues, mine progress, and resource development in general. The typical resident does not understand the power structures, processes, and legalities governing resource development; how the process proceeds; and what rights and opportunities they have within the process. Interviewees also observed that "Pond [is] not receiving priority hires, most hires are happening in Iqaluit" (NF7) and "contracts are going to Iqaluit companies instead of Pond" (NF1), despite the Mary River Inuit Impact Benefit Agreement (MRIIBA) provisions that stipulate local priority for hiring and contracting. However, it is possible 
that Inuit in Pond Inlet hold more power than they perceive, but do not always know how best to leverage and exercise it.

\subsection{Do the Pond Inlet Inuit Have Effective Institutions of Self-Government?}

The Nunavut Territory governance structure is complex and consists of at least four main layers: federal authority, territorial structures, land claim organizations, and municipal authorities.

Federal authority. As an administrative rather than an autonomous region of Canada, the Government of Nunavut can exercise only those powers delegated by the federal government. As a result, the Canadian government has a great deal of say in the operation of Nunavut, with the minister of Aboriginal Affairs and Northern Development Canada (AANDC) acting as commissioner for the territory and formal representative of the federal Crown. Canada's authority also stems from its role as a resource provider. The federal government allocates transfer payments and program funding to the territory and its institutions.

Nunavut territorial government. The Government of Nunavut is responsible for day-to-day territorial operations and has established three regionsKitikmeot, Kivalliq, and Qikiqtaaluk/Baffin (where Pond Inlet is located) - to organize the conduct of territorial operations at the local level. Laws for the territory are made by Nunavut's unicameral Legislative Assembly, which is composed of representatives of all residents of the territory (Inuit and nonInuit). Within the territorial government, there also are Nunavut territorial regulatory boards that help ensure compliance with the resource and comanagement agreements within the NLCA.

Inuit land claims organizations. Nuanvut Tunngavik Inc. (NTI) is the organization that represents Inuit under the NLCA and is, in essence, the Inuit government for the territory of Nunavut (see NTI, 2015b). Within NTI there are three regional Inuit bodies. These regionally based Designated Inuit Organizations (DIOs) were established under the NLCA to represent Inuit interests, ensure that the NLCA articles are honoured, and help operationalize Inuit self-determination. The regional body serving Pond Inlet is the Qikiqtani Inuit Association (QIA). NTI also includes Inuit regional development corporations, Inuit economic development organizations, Inuit investment corporations, and Inuit wildlife organizations.

Municipal governments. Elected municipal-level governing bodies are responsible for day-to-day operations in each hamlet. 
This layered structure is challenging for individuals to navigate because it can be unclear which level of government is jurisdictionally responsible for any given issue or circumstance. Interviewees in this study described these layers as a "regulatory nightmare" (NF31). They also explained that complicated inter-relationships and varying levels of trust exist among the governments, which in turn create an even more convoluted system of competing interests, perspectives, and goals.

The Harvard Project framework directs attention to institutions of Indigenous self-government. Because Pond Inlet is a predominantly Inuit community, hamlet-level governing institutions and the land claims organizations are a key set of structures through which community-level Indigenous self-governance can be exercised. In fact, this study found a strong level of support for hamlet government and hamlet-level municipal leaders. Interviewees expressed concern, however, that hamlet government was "very under resourced" (NF23) and severely understaffed, as evident in the comment that "turnover of hamlet [officials] is also a problem" (NF23).

The hamlet government's lack of both financial and human resources is a particular problem because, as noted above, it reduces the government's autonomy. Hamlet government cannot be an effective mechanism for Indigenous self-government if its reliance on territorial and federal governments for resources ties it more closely to those governments than is desired by community members. For example, because mining is a priority at the regional and territorial levels of government, some interviewees felt that all of the hamlet's economic "eggs [are] in the mining basket" (NF20), and that the municipal council ignored other important economic options, such as cultural tourism and arts and handicrafts.

Reflecting on their experience in the MRIIBA process, which was negotiated by QIA on behalf of Pond Inlet and four other communities, interviewees also raised doubts about how great a voice any one community can have in the region's decision-making process. Furthermore, some study participants expressed concern that DIOs could be influenced by financial incentives that favour a regional resource development project at the expense of local or community interests. The MRIIBA is supposed to ensure that Pond Inlet and the four other signatory communities specifically benefit from the mine through the payment of royalties, priority hiring arrangements, and education training programs. However, the agreement is a confidential document signed by the mining company and DIO on behalf of the five implicated communities. Because the IIBA is confidential, as is the case with all IIBAs and other legal documents of this nature, residents of Pond Inlet do not feel they have a sense of what they can expect from the mine, and so 
the process "[has] created a lot of mistrust between the community and the DIO" (NF7).

Worse, this mistrust appears to be compounded by the regional DIO's lack of transparency and communication: "There are questions about the royalties from Mary River, they were supposed to start in 2013 and benefit everyone but no one knows where they are or what's going on" (NF11). Interviewees felt that "[DIOs] need to advertise more and need to have an office in town" (NF3) and "help build community capacity to understand complex issues, educate about the process and where [the community fits in]" (NF20). Given the MRIIBA's crucial role in helping the community harness economic benefits from mining and offset negative effects, most respondents felt that QIA was not effectively representing community interests, and that as a result the Pond Inlet Inuit "are not steering [their] own ship" (NF20). At the same time, it is unclear whether local residents understand that DIOs are legally required to keep IIBA negotiations and content confidential, which means that the mistrust directed at QIA may be somewhat misplaced.

Other levels of government also appear inadequate as mechanisms through which the Pond Inlet Inuit can exercise self-government. Interviewees expressed substantial support for territorial-level government (more support, in fact, than they expressed for local or regional institutions), but still had mixed feelings about the Government of Nunavut's capacity to support Pond Inlet's specific development needs. Many felt that the Government of Nunavut is well aware of the challenges facing the territory, including the need to develop human capacity and strengthen institutional infrastructure (NEF, 2013), but that it has been ineffective in identifying solutions to these problems. Some respondents justified the slow progress at resolving these challenges by noting that the Government of Nunavut is relatively young, still learning, and "needs to mature" (NF37). For example, interview participants pointed out that the Government of Nunavut has yet to achieve the principles of Article 23 in the NLCA, which require proportional Inuit representation in government staffing (NTI, 2004), and that the underrepresentation of Inuit in managerial positions within the territorial government persists.

Whether Nunavut's extant governing institutions are capable of serving as mechanisms of self-government for the Pond Inlet Inuit is dependent on the community's ability to use this multifaceted political infrastructure to accomplish its goals. Do these governing institutions provide a base for the exercise of self-determination by providing rules and regulations that channel effective and legitimate decision making, and by operating in an efficient, fair, stable, and reliable manner (Cornell \& Kalt, 1992, 1998, 2007; 
Jorgensen \& Taylor, 2000)? Clearly, the key informants in this study do not feel that current institutional structures protect Inuit rights or that they work effectively for the exercise of Inuit self-determination.

\subsection{Do Pond Inlet's Decision-Making Structures-and Resultant Decisions-Reflect Cultural Match?}

The Harvard Project framework for successful community development emphasizes the importance of cultural match in decision-making institutions. American Indian nations whose governing institutions match or fit with contemporary community expectations of how decisions "ought" to be made tend to have more successful economies (Cornell \& Kalt, 1995, 1997). Native economies also may reflect cultural preferences. For example, more communitarian societies tend to have a comparatively greater proportion of tribally owned businesses, and more individualistic societies tend to have a greater proportion of small, entrepreneurial businesses (Cornell, Jorgensen, \& Kalt, 2011). One reason is that culture guides employment choices. But another is simply the effect of cultural match in governing institutions: culturally legitimate governing systems are more likely to create rules, laws, and policies that support the kind of economic development the community prefers (Cornell, Jorgensen, \& Kalt, 2011).

Pre-contact Inuit governance structures were grounded in customary laws and cultural taboos that the small autonomous Inuit groups spread across the Arctic region and relied on as the basis for establishing social order (Pauktuutit, 2006). Decision making within each group was inclusive and consensus-based. Community members were able to voice their concerns, ideas, and thoughts at council meetings and feel confident about their role in the community's present and future (Pauktuutit, 2006).

In contrast, when the Canadian federal government asserted administrative control over the Inuit, it imposed a hierarchical governing system and worked to engage communities in capitalist markets that rewarded individualism over collectivism. Even the newer Government of Nunavut continues the hierarchical form and embraces the market economy. Yet this political-economic approach is at odds with the sharing, inclusion, and consensus decision making that characterized traditional Inuit society (Pauktuutit, 2006). Study participants highlighted the importance of achieving a more acceptable balance between Western and Aboriginal belief systems, modern and traditional lifestyles, Canadian and Inuit governance, and among different age groups in Inuit society, and achieving the "difficult balance between economic development and traditional values" (NF1). 
Nonetheless, Pond Inlet based interviewees felt that balance has been very hard to achieve. Interviewees noted, "Inuit are still in the infant stage of the southern economic model, which goes against traditional Inuit group mentality where everyone has a role, no one is left out" (NF4), and that "Inuit had a survivor mentality traditionally but now have to change to a different mindset, it will take time" (NF7). Their perception was that in order to participate in current economic development, it is the Inuit who have to adapt to new realities, rather than the other way around.

Furthermore, the residents of Pond Inlet reported feeling that despite its use of consensus decision making, Nunavut's largely centralized governance structure was not compatible with their preferred model of highly local, consensus-based decision making. In fact, many Pond Inlet interviewees argued for a reassertion of local consensus-based processes, explaining that "consensus is the traditional and preferred way to make decisions, this should be kept in mind for development, consulting rather than dictating" (NF2), and that development decisions "should be a consensus of the whole community" (NF7).

Our final finding on cultural fit is a marked disconnect between local citizens' impressions of economic development decisions and territorial and regional decision makers' impressions. As noted, most local respondents felt that cultural considerations had not been effectively integrated into the economic development plan, that the mine dominated the agenda, and that Pond Inlet was not "steering its own ship" (NF20), despite guarantees in the NCLA for community input. By contrast, when questioned about the role of culture in shaping development, the regional and territorial decision makers interviewed felt that proposed projects match Inuit culture because "people won't participate if it doesn't" (NF37). They were also clear that for development to work, "culture needs to be integrated from the beginning" (NF39).

These conflicting impressions return attention to political decisionmaking processes and the fundamental question of cultural match. On the one hand, culturally legitimate political institutions do have the best chance of shaping development projects in a way that matches most people's expectations. On the other hand, the nature of human politics is that some people will always be "less happy" with certain decisions. If some community members' expectations for development projects are not met, culturally legitimate political institutions are also those that have the best chance of meeting the test of citizen support: "I don't agree with the outcome, but I do agree with the process." Distilled opinion from the interviews at Pond Inlet and Iqaluit suggest that current Nunavut institutions cannot meet this test. 


\subsection{Does Pond Inlet Have a Strategic Vision and the Leadership to}

Operationalize It?

Harvard Project results have repeatedly revealed that self-determination, and capable and culturally legitimate governing institutions, are vital for successful Native nation development (Cornell \& Kalt, 1992, 1998, 2007; Jorgensen \& Taylor, 2000). However, the results also suggest that the promise in these factors is difficult to realize if a Native nation lacks strategic vision; strategic plans; and committed, public-spirited leadership to implement its vision and plans. "Nation-building leadership" can inspire people to assert their inherent rights, restructure decision-making processes, and direct development that supports rather than undermines their collective future (Begay et al., 2007; Cornell et al., 2007; Cornell \& Kalt, 2007).

Predictably, residents of Pond Inlet have visions that span generations. "Sustainability should be the goal. Pond [Inlet] needs to be left with something once the mine is finished" (NF42). There is also an understanding that to achieve sustainable development, Pond Inlet needs to focus on creating businesses that are both diverse and balanced with cultural expectations. As one respondent summarized, "[You] can't expect that everyone wants to work at the mine" (NF37). For example, investing in the local Hunters and Trappers Organization (HTO) could "act on the business potential to provide the mine with country foods" (NF2). Other suggestions included opening a laundromat to service the mine, building a commercial fishery, and developing the tourist industry (also Dawson et al., 2014; Government of Nunavut, 2012).

In sum, participants in this study agreed that Pond Inlet residents had a vision for the future and the seeds of a strategy for implementation: "Inuit recognize [the] possibilities for the future. The Inuit way is to work together for change, this is respectful and powerful" (NF20). However, inspirational and motivational leadership is also needed to establish the institutional foundations and execute the strategy necessary for this kind of internally directed and longer-term development (Begay et al., 2007; Cornell \& Kalt, 2007; Cornell et al., 2007).

Pond Inlet residents felt that, in general, good leaders need to have strong educational backgrounds, communicate and listen well, and have cross-cultural perspectives. There was also a sense that for the community to realize its potential, it "needs the right leader at the right time" (NF1). Study participants were very clear that the future leadership of their community would come from the youth who needed to be mentored and encouraged. According to interviewees, Inuit youth in Nunavut will help the communities overcome the territory's considerable socio-economic issues 
and development challenges. Residents stated that "there are many capable young leaders in Nunavut" (NF32); "[we] need more young people in leadership roles" (NF12); and "More young people will run in the [territorial] election in four years, [this] brings hope" (NF38).

Interviewees' recognition that many leaders-not a single leader who may or may not be in control at any given time-are needed to build a strong system of self-government to sustain the community's vision and plans, generates hope for Pond Inlet's success. Nonetheless, action may need to be taken today to train emerging leaders in nation-building and inspire them to step forward.

\subsection{Conclusion}

Communities such as Pond Inlet, Nunavut, are at the forefront of economic

changes driven by the increasing importance of the resource economy for the Arctic region. They also are undertaking the challenging work of onthe-ground implementation of the land claim. In other words, now that the NLCA has been signed and self-determination is assumed, they are wrestling with the specifics of implementation, including questions about how implementation will proceed, which entities have the authority to decide, and how newly created institutions can adapt to challenges as Nunavut Inuit self-determination matures in practice.

Harvard Project findings emphasize the importance of self-determination as a key foundation for development success. In this research effort, we used the Harvard Project framework to conduct a case study of Pond Inlet to try to understand why Nunavut communities are struggling with resource and other development despite their ostensible self-determination via a settled land claim and established Inuit governance institutions.

The Harvard Project approach proved to be effective in teasing out some of the characteristics of community governance that may be problematic for Pond Inlet. Since the framework has not traditionally been applied at a community scale, but has historically been used to examine tribal nations across the United States where the context and development options differ significantly, this research further provided a basis for evaluating the usefulness of the approach in the Arctic. The applicability of the framework at a community scale rather than an entire Indigenous nation proved useful after a single case study, but it is recommended that additional case studies be conducted both to understand self-determined development for the Arctic region and to further test the framework. 
As other Aboriginal communities have found, achieving a settled land claim and instituting a system of governing structures does not complete the work of nation- and community-building. In this study, local residents of Pond Inlet describe feeling a lack of "real" decision-making power and control over resource development projects and benefits. One municipal government respondent summarized the sentiment: "We thought we were, but recently we realized, we are not steering our own ship" (NF20). In some ways, this finding is not entirely surprising. Growing pains related to the implementation of a land claim and the maturing of relatively new and formal Aboriginal institutions is expected. It can take generations to shed the history of colonization and for communities and societies to re-organize into a different social state.

In the short term, Pond Inlet continues to struggle without adequate capacity to realize its many goals. This study revealed numerous interrelated and nested aspects of governance that have led local Inuit to perceive a lack of decision-making power over community development pathways. For example, there is a complex institutional structure that lends more power to the federal government than may be desirable; there was a rapid transition from traditional consensus decision-making practices to current hierarchical structures that do not always create room for everyone's voice to be heard; there is a lack of sufficient communication between levels of government and regional organizations; and there is a feeling that the community leaders needed to deal with a resource-based economy are currently too young to be effective. Of particular note are respondent comments indicating that not all residents have a comprehensive understanding of the structures governing development, making it difficult, at times, for Pond Inlet Inuit to navigate the system and properly exercise their existing rights and powers.

Despite these challenges, the community has a vision for the future, ideas for local prosperity, and a relatively high level of confidence in the potential of their youth as future leaders-all ingredients for success. Considering the importance of self-determination, effective and culturally appropriate institutions, strategic vision, and sustained leadership in generating success, the residents of Pond Inlet have reason to be cautiously optimistic, albeit in the long term. Furthermore, the success of a recent lawsuit filed by NTI against the federal government for not upholding its obligations of the NLCA is indicative of the region's growing strength and capacity (see CBC, 2015b).

The fundamental elements of self-determination via a settled land claim agreement create a vital foundation, but a practiced understanding of how its implementation will occur may take time to be realized. As such, the study's findings reinforce and support the Harvard Project's conclusions that for 
viable, desirable, and sustainable local development to occur, Aboriginal, and in this case Inuit, institutions and culture matter-and so, too, does a people's own sense of power and control over their future. This research has shown that in Pond Inlet at least, attention must now shift toward improving the community's ability to leverage and control NLCA mechanisms, so that economic opportunities are more likely to result in meaningful, sustainable development. This will require improved capacity, better management, more active self-governance-while also fighting to ensure that Inuit culture is an important component in all aspects of decision making.

\section{Acknowledgements}

Funding for this project was provided by the Social Sciences and Humanities Research Council of Canada (SSHRC); the Environment, Society, and Policy Group (www.espg.ca); the Students for Canada's North program; and the Northern Scientific Training Program. We would like to gratefully acknowledge the participants involved in this study and the community of Pond Inlet for welcoming us once again into their community.

\section{Authors}

Roger Ritsema graduated with a Master's degree in Geography from the University of Ottawa in the fall of 2014, and has been working in the Treaty 3,5 , and 9 areas of northwest Ontario.

Jackie Dawson is the Canada Research Chair in Environment, Society, and Policy and associate professor of geography at the University of Ottawa.

Miriam Jorgensen is research professor at the Udall Center for Studies in Public Policy and research director of the Native Nations Institute, both at the University of Arizona; she is also research director of the Harvard Project on American Indian Economic Development and a professorial fellow at the Melbourne School of Government at the University of Melbourne.

Brenda Macdougall is the Chair of Métis Research at the University of Ottawa, where she is also an associate professor of geography; she was previously with the Department of Native Studies, University of Saskatchewan.

\section{References}

AANDC (Aboriginal Affairs and Northern Development Canada). (2012). Mineral exploration and geoscience overview. Retrieved from, http://www.miningnorth. com/_rsc/site-content/library/publications/2012_NU_EXPLORATION_ OVERVIEW.pdf

ACIA (Arctic Climate Impact Assessment). (2004). Impacts of a warming Arctic. Summary report of the Arctic Climate Impact Assessment. Cambridge, U.K: Cambridge University Press. 
Angell, A. C., \& Parkins, J. R. (2010). Resource development and aboriginal culture in the Canadian North. Polar Record, 47(1), 67-79.

Begay, M. A., Cornell, S., Jorgensen, M., \& Pryor, N. (2007). Rebuilding native nations: What do leaders do. In M. Jorgensen (Ed.), Rebuilding native nations: Strategies for governance and development (pp. 275-295). Tucson: University of Arizona Press.

Berry, A. (2009). Two forests under the big sky: Tribal v. federal management (PERC Policy Series No. 45). Bozeman, MT: Author.

BIMC (Baffinland Iron Mines Corporation). (2012). Mary River Project: Final environmental impact statement, popular summary. Retrieved from http:// http:// www.baffinland.com.vs2.korax.net/wp-content/themes/baffinland/images/ POP_Eng_sm.pdf

Buell, M. (2006). Resource extraction development and well-being in the North: A scan of the unique challenges of development in Inuit communities. Ottawa, ON: National Aboriginal Health Organization.

CBC. (2015a, July 14). Baffinland Iron Mines granted land use plan exemption by federal minister. Retrieved from http://www.cbc.ca/news/canada/north/baffinland-ironmines-granted-land-use-plan-exemption-by-federal-minister-1.3151834

CBC (2015b, March 9). Nunavut Tunngavik, Canada, reach tentative deal in $1 B$ lawsuit. Retrieved from http://www.cbc.ca/news/canada/north/ nunavut-tunngavik-canada-reach-tentative-deal-in-1b-lawsuit-1.2987957

Coates, K., \& Powell, J. (1989). The Modern North: People, politics, and the rejection of colonialism. Toronto, Canada: James Lorimer \& Company.

Cornell, S., Jorgensen, M., \& Kalt, J. P. (2011). Is there only one cultural path to development? Sustainable heterogeneity among contemporary American Indian nations. Native Nations Institute, University of Arizona.

Cornell, S., Jorgensen, M., Kalt, J. P., \& Spilde Contreras, K. (2007). Seizing the future: Why some native nations do and others don't. In M. Jorgensen, (Ed.), Rebuilding native nations: Strategies for governance and development (pp. 296-320). Tucson: University of Arizona Press.

Cornell S., Jorgensen, M., Rainie, S. C., \& Starks, R. (2013). Self-determination and Native American health care: The shift to tribal control. Unpublished manuscript, Native Nations Institute, Udall Center for Studies in Public Policy, University of Arizona.

Cornell, S., \& Kalt, J. (1992). Reloading the dice: Improving the chances of economic development on American Indian reservations. In S. Cornell \& J. Kalt (Eds.), What can tribes do? Strategies and institutions in American Indian economic development (pp. 1-59). Los Angeles, CA: American Indian Studies Center, University of California.

Cornell, S., \& Kalt, J. (1993). Culture as explanation in racial and ethnic Inequality: American Indians, reservation poverty, and collective action. (Report 93-2, Project Report Series). Cambridge, MA: Harvard Project on American Indian Economic Development, John F. Kennedy School of Government, Harvard University. 
Cornell, S., \& Kalt, J. (1995). Where does economic development really come from? Constitutional rule among the contemporary Sioux and Apache. Economic Inquiry, 33 (July), 402-26.

Cornell, S., \& Kalt, J. (1997). Successful economic development and heterogeneity of governmental form on American Indian reservations. In M. S. Grindle (Ed.), Getting good government: Capacity building in the public sectors of developing countries (pp. 257-96). Cambridge, MA: Harvard Institute for International Development.

Cornell, S., \& Kalt, J. (1998). Sovereignty and nation-building: The development challenge in Indian country today. American Indian Culture and Research Journal, 22(3), 187-214.

Cornell, S., \& Kalt, J. (2000). Where's the glue: Institutional and cultural foundations of American Indian economic development. Journal of Socio-Economics, 29, 443-70.

Cornell, S., \& Kalt, J. (2007). Two approaches to economic development on American Indian Reservations: One works, the other doesn't. In M. Jorgensen, (Ed.), Rebuilding native nations: Strategies for governance and development (pp. 3-33). Tucson, AZ: University of Arizona Press.

CPC (Canadian Polar Commission). (2014). The state of northern knowledge in Canada. Retrieved from http://www.polarcom.gc.ca/sites/default/files/northen_ knowledge_report_english.pdf

Dawson, J., Johnston, M. E., \& Stewart, E. J. (2014). Governance of Arctic expedition cruise ships in a time of rapid environmental and economic change. Ocean and Coastal Management, 89(1), 88-99.

Dixon, M., Shelton, B. L., Roubideaux, Y., Mather, D., \& Mala Smith, C. (1998). Tribal perspectives on Indian self-determination and self-governance in health care management. Denver, CO: National Indian Health Board.

Dooley, D. (1995). Social research methods ( $3^{\text {rd }}$ Ed.). New Jersey, NY: Prentice Hall.

Duhaime, G., Bernard, N., Fréchette, P., Maillé, M-A., Morin, A., \& Caron, A. (2003). The mining industry and the social stakes of development in the Arctic. Quebec City, Quebec, Canada Research Chair in Aboriginal Comparative Condition.

Dunn, K. (2010). Qualitative research and its place in human geography. In I. Hay (Ed.), Qualitative research methods in human geography (3 ${ }^{\text {rd }}$ Ed.) (pp. 101-138). Toronto, ON: Oxford University Press.

Gauthier, D. L., Bird, K. J., Charpentier, R. R., Grantz, A., Houseknecht, D. W., Klett, T. R., \& Wandrey, C. J. (2009). Assessment of undiscovered oil and gas in the Arctic. Science, 324(5931), 1175-1179.

Glaser, B., \& Strauss, A. (1967). The discovery of grounded theory: Strategies for qualitative research. Chicago: Aldine.

Goldberg, C., \& Champagne, D. (2012). Captured justice: Native nations and public law 280. Durham, NC: Carolina Academic Press.

Government of Canada. (2009). Canada's northern strategy: Our North, our heritage, our future. Ottawa: Federal Interlocutor for Métis and Non-Status Indians, Indian Affairs and Northern Development Canada. 
Government of Nunavut. (2007). Parnautit-A foundation for the future: Mineral and mining strategy.Iqaluit, Nunavut: Department of Economic Development and Transportation. Retrieved from, http://www.edt.gov.nu.ca/docs/parnautit_eng. pdf

Government of Nunavut (2012). Tunngasaiji: A tourism strategy for Nunavummiut. Iqaluit, Nunavut: Nunavut Tourism. Retrieved from http://www.nunavut.ca/ files/07\%20GN\%20Tourism\%20Strategy.pdf

IPCC (International Panel on Climate Change). (2014). Summary for policymakers. In O. Edenhofer, R. Pichs-Madruga, Y. Sokona, E. Farahani, S. Kadner, K. Seyboth, A. Adler, I. Baum, S. Brunner, P. Eickemeier, B. Kriemann, J. Savolainen, S. Schlömer, C. von Stechow, T. Zwickel, \& J.C. Minx (Eds.), Climate change 2014, Mitigation of climate change. Contribution of working group III to the fifth assessment report of the intergovernmental panel on climate change. Cambridge, UK and New York: Cambridge University Press.

ITK (Inuit Tapiriit Kanatami) \& NRI (Nunavut Research Institute). (2007). Negotiating research relationships with Inuit communities: A guide for researchers. Ottawa and Iqaluit: Inuit Tapiriit Kanatami and Nunavut Research Institute.

HPAIED. (2015). Harvard Project on American Indian economic development. Retrieved from http://hpaied.org/

Jorgensen, M. (2000). Bringing the background forward: Evidence from Indian country on the social and cultural determinants of economic development. Unpublished doctoral dissertation, Harvard University.

Jorgensen, M. (2004). History's lesson for HUD and tribes. (Joint occasional papers on native affairs, No. 2004-01). Tucson and Cambridge: Native Nations Institute for Leadership, Management, and Policy, University of Arizona, and Harvard Project on American Indian Economic Development, Harvard University.

Jorgensen, M., \& Taylor, J. (2000). What determines Indian economic success? Evidence from tribal and individual Indian enterprises. Red Ink, 8(2), 45-51.

Krepps, M. B., \& Caves, R. E. (1994). Bureaucrats and Indians: Principal-agent relations and efficient management of tribal forest resources. Journal of Economic Behavior and Organization, 24(July), 133-151.

Krueger, R. A. (1988). Focus groups: A practical guide for applied research. Thousand Oaks, CA: Sage.

Lemmen, D. S., Warren, F. J., Lacroix, J., \& Bush, E. (Eds.). (2008). From impacts to adaptation: Canada in a changing climate. Ottawa: Government of Canada.

NEF (Nunavut Economic Forum). (2013). 2013 Nunavut economic outlook: Nunavut's next challenge: Turning growth into prosperity. Retrieved from http://www.neds2. ca/documents/2013_Nunavut_Economic_(FINAL)_Jan_28_2014.pdf

NNI (2015). Native Nations Institute. Tucson: University of Arizona. Retrieved from, www.nni.arizona.edu 
NSCG (North Sky Consulting Group). (2009). Qanukkanniq? The GN report card. Retrieved from http://www.tunngavik.com/wp-content/uploads/2010/12/gnreport-card-analysis-and-recomm-10-09.pdf

NTI (Nunavut Tunngavik Incorporated). (1997). Mining policy. Retrieved from http:// www.tunngavik.com/documents/publications/1997-12-00-Mining-Policy.pdf

NTI (Nunavut Tunngavik Incorporated). (2004). TUKISITTIARNIQSAUJUMAVIIT? A plain language guide to the Nunavut Land Claims Agreement. Ottawa: St. Joseph Print Group.

NTI (Nunavut Tunngavik Incorporated). (2015a). Nunavut Land Claims Agreement. Retrieved from http://nlca.tunngavik.com/

NTI (Nunavut Tunngavik Incorporated). (2015b). Nunavut Tunnagavik Incorporated. Retrieved from http://www.tunngavik.com/

Parlee, B., \& Furgal, C. (2012). Well-being and environmental change in the Arctic: A synthesis of selected research from Canada's International Polar Year Program. Climatic Change, 115(1), 13-34.

Patton, M. Q. (2002). Qualitative evaluation and research methods ( $3^{\text {rd }}$ Ed.). Beverly Hills, CA: Sage.

Pauktuutit (Inuit Women of Canada). (2006). The Inuit way: A guide to Inuit culture. Retrieved from, http://www.uqar.ca/files/boreas/inuitway_e.pdf

Peterson, K. (2012). Community experiences ofmining in Baker Lake, Nunavut. Unpublished master's thesis, University of Guelph. Retrieved from http://atrium.lib. uoguelph.ca:8080/xmlui/bitstream/handle/10214/3548/KCRPetersonThesisFial. pdf?sequence $=11 /$

Prowse, T. D., Furgal, C., Chouinard, R., Melling, H., Milburn, D., \& Smith, S. L. (2009). Implications of climate change for economic development in Northern Canada: Energy, resource, and transportation sectors. Ambio, 38(5), 272-280.

RESDA (Resources and Sustainable Development in the Arctic). (2012). ReSDA newsletter. Issue \#1. Retrieved from http://yukonresearch.yukoncollege.yk.ca/ resda/wp-content/uploads/sites/2/2013/09/Final-ReSDA-newsletter-printOct2012.pdf

RESDA (Resources and Sustainable Development in the Arctic). (2013). ReSDA newsletter. Issue \#2. Retrieved from http://yukonresearch.yukoncollege.yk.ca/ resda/wp-content/uploads/sites/2/2013/09/ReSDA-Newsletter-Summer-Fall2013-final-webv.pdf

Rhéaume, G., \& Caron-Vuotari, M. (2013). The future of mining in Canada's North. Retrieved from http://www.miningnorth.com/_rsc/site-content/library/ Final-13-201_FutureofMining_CFN.pdf

Secor, J. (2010). Social surveys, interviews, and focus groups. In B. Gomez \& J. P. Jones III (Eds.), Research methods in geography (pp. 195-205). West Sussex, UK: Blackwell Publishing. 
SEDSG (Sivummut Economic Development Strategy Group). (2003). Nunavut economic development strategy: Building a foundation for the future. Retrieved from http://www.nunavuteconomicforum.ca/public/files/strategy/NUNAVUTE.PDF

Simeone, T. (2007). The Harvard Project on American Indian economic development: Findings and considerations. Ottawa: Parliamentary Information and Research Service. Library of Parliament. Retrieved from http://www.parl.gc.ca/Content/ LOP/researchpublications/prb0737-e.htm

Statistics Canada. (2011). Population growth rate (in percentage) of provinces and territories, 2001 to 2006 and 2006 to 2011 (figure 3). Census 2011, analytical products-The Canadian population in 2011: Population counts and growth. Retrieved from https:// www12.statcan.gc.ca/census-recensement/2011/as-sa/98-310-x/2011001/fig/fig3eng.cfm

Statistics Canada. (2012). Population estimates, age distribution and median age as of July 1, 2012, Canada, provinces and territories (table 2.1). Annual demographic estimates: Canada, provinces and territories-population by age and sex. (Statistics Canada Catalogue no. 91-215-X). Retrieved from http://www.statcan.gc.ca/pub/91215-x/2012000/t583-eng.htm

Statistics Canada. (2013). Pond Inlet, HAM, Nunavut (code 6204020) (table). National Household Survey (NHS) profile, 2011. (Statistics Canada Catalogue no. 99-004XWE). Retrieved from http://www12.statcan.gc.ca/nhs-enm/2011/dp-pd/prof/ index.cfm?Lang=E

Strauss, A., \& Corbin, J. (1990). Basics of qualitative research: Grounded theory procedures and techniques. Newbury Park, CA: Sage.

Trosper, R. (1995). Traditional American Indian economic policy. American Indian Cultural and Research Journal, 19(1), 65-95.

Trosper, R. L., Nelson, H., Hoberg, G., Smith, P., \& Nikolakis, W. (2008). Institutional determinants of profitable commercial forestry enterprises among First Nations in Canada. Canadian Journal of Forest Research, 38, 226-238.

Wakeling, S., Jorgensen, M., Michaelson, S., \& Begay, M. (2001). Policing on American Indian reservations: A report to the National Institute of Justice. Washington, DC: National Institute of Justice, United States Department of Justice.

Waldie, P. (2011, May 14). A railway to Arctic riches: Economic boom or environmental threat? The Globe and Mail. Retrieved from http://www. theglobeandmail.com/report-on-business/industry-news/energy-andresources/a-railway-to-arctic-riches-economic-boom-environmental-threat/ article4259449/?page=all

White, G. (2009). Governance in Nunavut: Capacity vs. culture? Journal of Canadian Studies, 43(2), 57-81.

Zaferatos, N. C. (2015) Planning the American Indian reservation: From theory to empowerment. Syracuse, NY: Syracuse University Press. 